\title{
Influence of plant immunity inducers on the quality of apple fruit in Abkhazia
}

\author{
Oksana Belous ${ }^{1, *}$, Georgiy Pantiya ${ }^{1,2}$, Yelena Mikhailova $^{1}$, Natalia Karpun $^{1}$, and Liosik \\ $\mathrm{Ayba}^{2}$ \\ ${ }^{1}$ Russian Research Institute of Floriculture and Subtropical Crops, Yana Fabritsiusa Street, 2/28, \\ Sochi, 354002, Russia \\ ${ }^{2}$ Institute of Agriculture of Academy of Sciences of Abkhazia, Gulia Street, 22, Sukhum, 384900, \\ Republic of Abkhazia
}

\begin{abstract}
The quality of fruit depends largely on the growing area of the crop, the intensity of disease development, damage by pests, as well as on the treatment of plants with compounds of various chemical natures. When introducing the immunity inducers Albit ${ }^{\circledR}$ (poly-beta-hydroxybutyric acid), Immunocytophyte ${ }^{\circledR}$ (arachidonic acid ethyl ether) and Ecogel ${ }^{\circledR}$ (chitosan lactate) into apple tree protection systems, an urgent task is to study their influence on the quality of fruits. Research was conducted on apple trees (cultivars Idared and Golden Rangers) in the conditions of the Republic of Abkhazia (Gulripsh district). When treated with immunity inducers, the genotypic features of the cultivars were clearly revealed. For the susceptible Idared cultivar, it is more significant to use Ecogel ${ }^{\circledR}$, which causes the active synthesis of soluble solids, pectin, soluble sugars, ascorbic acid, and as a result, an increase in the sugar-acid index. At the same time, a relatively resistant cultivar Golden Rangers has a similar effect when treated with Immunocytophyte ${ }^{\circledR}$. Treatment with Albit ${ }^{\circledR}$ has the same effect on the synthesis of soluble organic acids in the fruits of the studied apple cultivars, reducing their amount. The results obtained indicate the need for a cultivar-specific approach in the application and selection of plant immunity inducers.
\end{abstract}

\section{Introduction}

Among the ways to improve the existing systems for protecting apple trees from fungal diseases, we can single out the use of plant immunity inducers [1]. The protective action of immunity inducers is based on the activation of natural plant resistance mechanisms that block the pathogen development [2]. In many cultures, immune inducers of various natures have proved to be not only effective means of reducing the degree of development of fungal diseases, but also a means of increasing the yield and quality of fruits [3-5].

"Corresponding author: oksana191962@mail.ru 
To develop effective protection of plants from diseases (including Apple trees from scab), it is necessary to evaluate the effect of protection agents in a specific zone [6]. Thus, immunity inducers proved to be an effective tool in apple tree protection systems against scab in Abkhazia, significantly reducing the degree of scab development [7].

The quality of fruit depends largely on the growing area of the crop, the intensity of disease development, damage by pests, as well as on the treatment of plants with compounds of various chemical natures [8-10]. In this regard, when introducing immunity inducers into apple tree protection systems, it is an urgent task to study their influence on the biochemical indicators of fruit quality. The purpose of this study is to assess the influence of the immunity inducers Albit $\AA$, Immunocytophite ${ }^{\circledR}$ and Ecogel $\AA$ used in apple protection systems from scab in Abkhazia on the quality of apple fruit.

\section{Materials and methods}

The experiment was started in the year 2016 throughout year 2019 in experimental Apple orchards $(3 \times 1.5 \mathrm{~m}$ planting scheme, 1 ha area, M9 rootstock on a espalier with drip irrigation) of the Institute of Agriculture of the Academy of Sciences of Abkhazia (Gulripsh district, Abkhazia).

The study involved apple cultivars with different scab resistance - Idared (susceptible cultivar) and Golden Rangers (relatively resistant cultivar). Both cultivars are latematuring, high-yielding, and common in industrial plantings in the region. The experience was based on generally accepted methods.

The experiment included plant immunity inducers of a different chemical nature Albit ${ }^{\circledR}$, poly-beta-hydroxybutyric acid-based, added by magnesium sulphate $(29.8 \mathrm{~g} / \mathrm{kg})$, potassium phosphoric acid $(91.1 \mathrm{~g} / \mathrm{kg})$, potassium nitric acid $(91.2 \mathrm{~g} / \mathrm{kg})$, carbomide $(181.5 \mathrm{~g} / \mathrm{kg})$; Immunocytophyte $\AA$, arachidonic acid ethyl ether-based; Ecogel $\AA$, chitosan lactate-based. The first preparation activates the salicylate pathway of non-specific immunity, the second one activates the jasmonate pathway, and the third one activates both of these pathways.

Scheme of the experiment (the variants were laid in 5-fold repetition):

1. Control: water treatment, without fungicides and plant immunity inducers;

2. Standard (production treatment): Score ${ }^{\circledR}$, (diphenoconazole, $250 \mathrm{~g} / \mathrm{l}$ ) 0.2 1/ha - I tenday period of May; Topaz ${ }^{\circledR}$, (penconazole, $\left.100 \mathrm{~g} / \mathrm{l}\right) 0.3 \mathrm{l} / \mathrm{ha}$ - I ten-day period of June; Strobitek ${ }^{\circledR}$, (cresoxime-methyl, $500 \mathrm{~g} / \mathrm{kg}$ ) $0.2 \mathrm{~kg} / \mathrm{ha}$ - I and III ten-day periods of July;

3. Albit ${ }^{\circledR}$, (poly-beta-hydroxybutyric acid, $6.2 \mathrm{~g} / \mathrm{kg}$ ), $250 \mathrm{ml} / \mathrm{ha}$ with $1 / 2$ of the fungicides consumption rate, 4 treatments: I ten-day period of May; I ten-day period of June; I and III ten-day period of July;

4. Immunocytophyte ${ }^{\circledR}$, (arachidonic acid ethyl ester, $0.167 \mathrm{~g} / \mathrm{kg}$ ), $0.6 \mathrm{~g} / \mathrm{ha}$ with $1 / 2$ of the fungicides consumption rate, 4 treatments: I ten-day period of May; I ten-day period of June; I and III ten-day period of July;

5. Ecogel ${ }^{\circ}$, (chitosan lactate $\left.30 \mathrm{~g} / \mathrm{l}\right), 1.5 \mathrm{l} / \mathrm{ha}$ with $1 / 2$ of the fungicides consumption rate, 4 treatments: I ten-day period of May; I ten-day period of June; I and III ten-day period of July.

The terms of treatment with tank mixtures of fungicides with plant immunity inducers corresponded to the production ones. Diagnosis of scab development was performed on the 7 th day after treatment.

The biochemical composition of fruits was studied at the stage of consumer maturity according to the following indicators: soluble dry substances (SS) by drying to a constant weight, mono- and disaccharides by the Bertrand method, titrated (organic) acids (TA) by titration in the presence of an indicator, ascorbic acid (AA) by the iodometric method, sugar 
acid index (SAI), pectin substances (PS) by deesterification [11]. All chemical analyses were performed three times over.

Statistical processing of experimental data was performed using the ANOVA package in STATGRAPHICS Centurion XV (version 15.1.02, StatPoint Technologies) and MS Excel 2007. The significance of the difference between the average values at $p<0.05$ was considered statistically significant. The results of the study are expressed as an arithmetic mean with a standard deviation.

\section{Results and discussion}

Studies have shown that the immunity inducers studied have good anti-stress activity. Their use allows you to restore the normal physiological state of plants and, consequently, stimulate synthetic processes that affect the quality of fruits.

As a rule, for different types of processing, fruits with a certain set of biochemical indicators are selected, as evidenced by the content of dry substances. Apples with high dry matter content are excellent raw materials for making fruit powders and dried fruits. The more of these substances are in apples, the higher the yield of the finished product [12-15]. On average, according to experience, the content of soluble solids in fruits ranges from 1.57 to $17.33 \%$. At the same time, the fruit of the Golden Rangers cultivar has slightly more SS than that of the Idared cultivar. The use of drugs leads to an active accumulation of SS (Fig. 1).
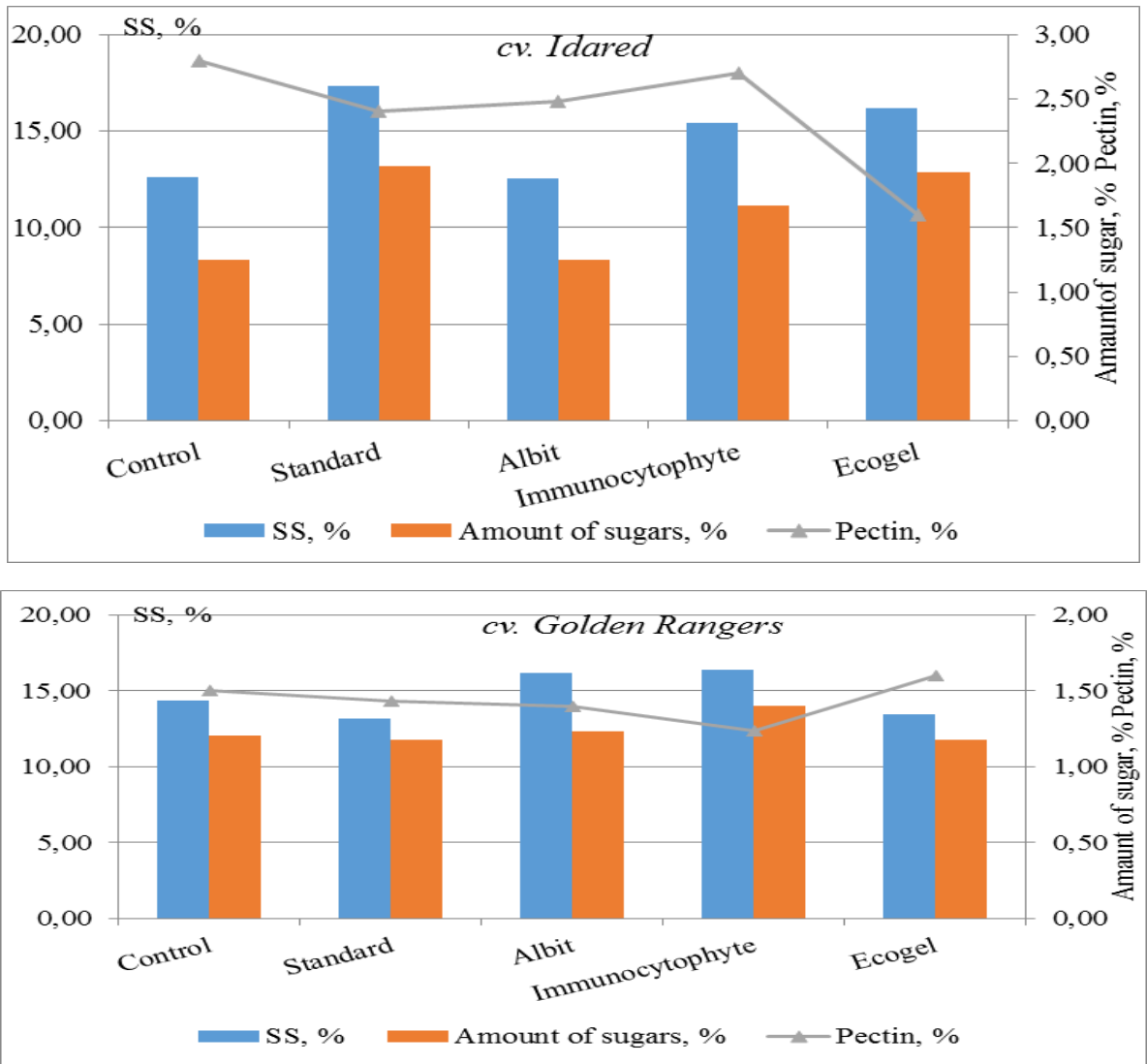

Fig. 1. Influence of plant immunity inducers on the content of soluble solids (SS), sugars and pectin substances (PS) in apple fruit 
The reaction of the cultivar to the drug depends on its genotype, in particular, on the degree of resistance of the variety to pathogens (Idared, unlike Golden Rangers, differs in average susceptibility to the pathogen scab). In fruits of the Idared cultivar, a significant increase in SS is caused by the use of Immunocytophyte ${ }^{\circledR}$ and Ecogel ${ }^{\circledR}$, while in fruits of the Golden Rangers cultivar, a slight increase is observed when treated with Immunophytophyte ${ }^{\circledR}$ and Albit $\AA$.

The main amount of soluble solids is sugar, the content of which depends on the location and areas of apple growing [16-19]. The content of sugars in fruits is influenced by the use of immunity inducers, and in this case, this effect is cultivar-specific. In susceptible Idared, active synthesis of sugars (up to $11-13 \%$ with $8 \%$ control) occurs during production treatment and in variants with Immunocytophyte ${ }^{\circledR}$ and Ecogel ${ }^{\circledR}$. In fruits of the Golden Rangers cultivar, an insignificant increase in sugars occurs only on the variant with Immunocytophyte ${ }^{\circledR}$ (Fig. 1).

Many studies have established the important role of pectin in human nutrition $[16,18$ 20]. Pectin substances that have a pronounced biological effect neutralize and remove heavy metals from the body. One of the richest sources of PS is apple fruit. The PS content in the fruits of all variants of the experiment is on average 1.23-2.80\%, and the differences between the variants are significant (LSD $(\mathrm{P} \leq 0.05)-0.30$ for the Idared cultivar and LSD $(\mathrm{P} \leq 0.05)-0.10$ for the Golden Rangers cultivar). In the accumulation of pectin, there are differences in variants associated not only with the peculiarity of the cultivar, but also with the inducer used. A decrease in PS synthesis was observed in the fruits of the Idared cultivar during production treatment and processing with Albit ${ }^{\circledR}$ and Ecogel ${ }^{\circledR}$, in the Golden Rangers cultivar - in the variant with Immunocytophyte ${ }^{\circledR}$.

Titrated (organic) acids affect the nutritional value and technological qualities of fruits $[14-16,20]$. In all variants of the experiment, the content of TA is from 0.47 to $0.77 \%$, while a significant influence of immunity inducers on the synthesis of these substances in the fruit was revealed. It is interesting to note that, both the susceptible Idared cultivar and the relatively scab-resistant Golden Rangers production treatment, as well as treatment with Albit ${ }^{\circledR}$, caused activation of the synthesis of titrated acids $(\operatorname{LSD}(\mathrm{P} \leq 0.05)=0.06)$.

The ratio of sugar to acid, or sugar-acid index (SAI), characterizes the taste of fruit, which at high acidity or low sugar content is about 10 units $[12,15,16]$. Fruits with a sugar-acid index of 15 to 30 units are most valued [12]. In our experiment, the SAI of fetuses was in the range of 12.50-29.28 units. The reaction of cultivars to the applied drugs once again emphasizes varietal characteristics in resistance to biotic factors: in the susceptible Idared cultivar, a significant increase was observed in the variants with Immunocytophyte ${ }^{\circledR}$, Ecogel ${ }^{\circledR}$ and during production treatment, while Golden Rangers had either a decrease in SAI (variants with Ecogel ${ }^{\circledR}$ and production treatment), or the effect of the drugs was insignificant (Albit ${ }^{\circledR}$ and Immunocytophyte $\left.{ }^{\circledR}\right)$.

The content of vitamins (in particular, ascorbic acid) in apple fruit is usually insignificant, but in combination with other substances, they play an important role [13, 2123]. The amount of ascorbic acid is an unstable sign, depending on the species characteristics, age-related changes in plants, the prevailing meteorological conditions of the year and the drugs used [19]. We noted that differences in the accumulation of AA in fruits are justified by the characteristics of the cultivar's reaction to the drug used. Thus, in the susceptible Idared, a significant increase in vitamin $\mathrm{C}$ synthesis $(\mathrm{LSD}(\mathrm{P} \leq 0.05)=2.26)$ is observed during production treatments and in the variant with Ecogel $\AA$ (Fig. 2). 


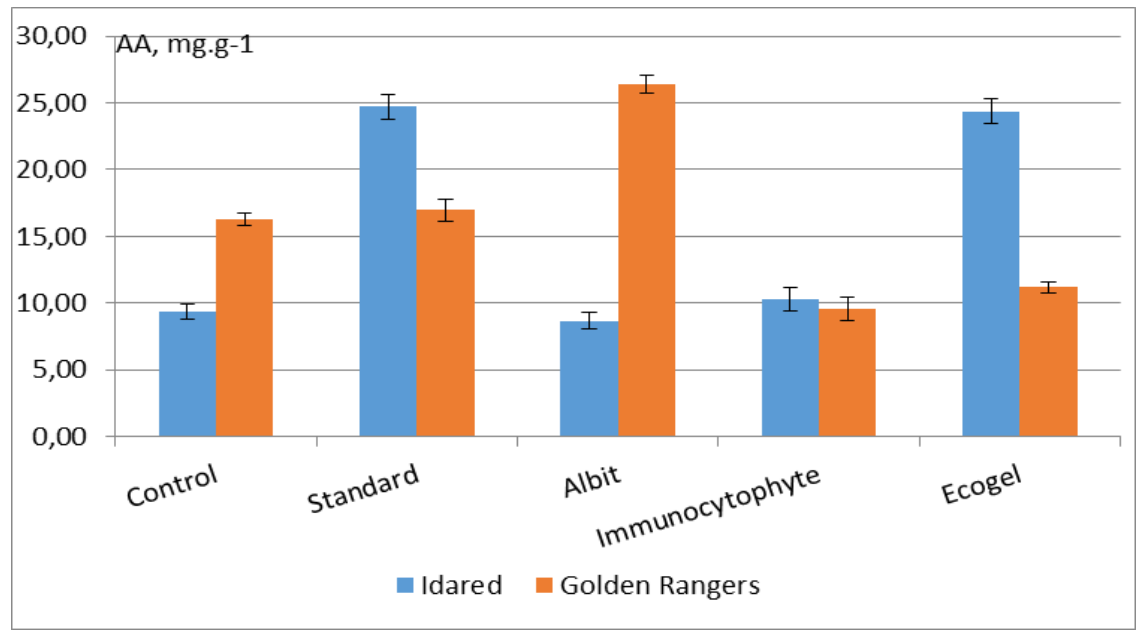

Fig. 2. Influence of immunity inducers on the content of ascorbic acid (AA) in the apple fruit

In a relatively resistant cultivar of Golden Rangers, no less significant activation of AH synthesis was detected during treatment with Albit ${ }^{\circledR}$ and Immunocytophyte ${ }^{\circledR}$ (LSD $(\mathrm{P} \leq$ $0.05)=2.18$ ). It is important that ascorbic acid, as a component of the antioxidant system, participates not only in the mechanisms of protection from abiotic stress, but also actively protects plants from biotic stressors, including pathogens [16, 24].

\section{Conclusion}

Thus, when treating with plant immunity inducers, genotypic features in the reaction to drugs are clearly manifested, namely, in the activation of protective mechanisms. For the susceptible Idared cultivar, it is more significant to use Ecogel ${ }^{\circledR}$, which causes the active synthesis of soluble solids, pectin, soluble sugars, ascorbic acid, and as a result, an increase in the sugar-acid index. At the same time, a relatively resistant cultivar of Golden Rangers has a similar effect, mainly, treatment with Immunocytophyte ${ }^{\circledR}$. Treatment with Albit ${ }^{\circledR}$ has the same effect on the synthesis of titrated acids-reducing their amount both in the fruits of the Idared cultivar and the Golden Rangers cultivar.

As many authors note, salicylates and jasmonate signaling pathways provide transcriptional activation of different groups of plant immunity system genes, and these signaling pathways are antagonistic [24]. In the salicylate defense pathway, the resulting salicylic acid enhances the synthesis, protection and restoration of the structure of nucleic acids and proteins important for the existence of plants [24-27], which is the basis for providing synthetic processes and accumulation of biochemical components. In the jasmonate pathway, the resulting jasmonates, enhancing the action of elicitors, activate protective mechanisms [24-27]. Differences in the mechanisms of protection induced during treatment with immunity inducers of different chemical nature explain the differences in the accumulation of biochemical components in the fruit of apple cultivars with different degrees of resistance, which necessitate a cultivar-specific approach to the use and selection of plant immunity inducers. 


\section{References}

1. M. Thakur, B.S. Sohal, ISRN Biochemistry, $2013 \quad$ (2013) https://doi.org/10.1155/2013/762412

2. N.N. Karpun, E.B. Yanushevskaya, Ye.V. Mikhailova, Sel'skokhozyaistvennaya Biologiya (Agricultural Biology). Ser. Plant Biology, 50(5), 540-549 (2015) https://doi.org/10.15389/agrobiology.2015.5.540eng

3. J.L. Coquoz, A.J. Buchala, P. Meuwly, J.P. Metraux, Phytopthology, 85, 1219-1224 (1995) https://doi.org/10.1094/Phyto-85-1219

4. E. Llorens, P. Garcia-Agustin, L. Lapena, Scientia Agricola (Piracicaba, Braz.), 74(1), 90-100 (2017) https://doi.org/10.1590/1678-992x-2016-0012

5. L.I. Pusenkova, E.Yu. Il'yasova, I.V. Maksimov, O.V. Lastochkina, Sel'skokhozyaistvennaya Biologiya (Agricultural Biology). Ser. Plant Biology, 50(1), 115123 (2015) https://doi.org/10.15389/agrobiology.2015.1.115eng

6. A. Batukaev, S. Levchenko, E. Ostroukhova, V. Boyko, I. Peskova, P. Probeigolova, D. Belash, N. Lutkova, BIO Web of Conferences, 15, 01012 (2019) https://doi.org/10.1051/bioconf/20191501012

7. O.O. Beloshapkina, T.Kh. Kumakhova, N.N. Wahsheh. News of the Timiryazev Agricultural Academy, 4, 52-63 (2014).

8. Ye.V. Mikhailova, N.N. Karpun, E.B. Yanushevskaya, E.A. Mel'kumova, Proceedings of Voronezh State University, 2(57), 48-58 (2018) https://doi.org/10.17238/issn2071-2243.2018.2.48 (In Russ.)

9. R. Nestby, F. Lieten, D. Pivot, C. Lacroix, M. Tagliavini. International Journal of Fruit Science, 5, 139-156 (2006) https://doi.org/10.1300/J492v05n01 13

10. G. Brunetto, G.W.B. de Melo, M. Toselli, M. Quartieri, M. Tagliavini,. Rev. Bras. Frutic. [online], 37(4), 1089-1104, (2015) https://doi.org/10.1590/0100-2945-103/15

11. A.I. Ermakov, V.V. Arasimovich, M.I. Smirnova-Ikonnikova, N.P. Yarosh, G.A. Lukovnikova. L.: Kolos, (1972) (In Russ.)

12. N.I. Nenko, G.K. Kiseleva, E.V. Ulyanov, V.A.Karavaeva. International Research Journal, 5(47), 87-89, (2016) https://doi.org/10.18454/IRJ.2016.47.002

13. D.A. Magdas, A. Dehelean, R. Puscas. Scientific World Journal, 2012, 878242, Published online (2012), https://doi.org/10.1100/2012/878242

14.E.G. Bazba, O.G. Belous, A.P. Kachurina. Subtropical and ornamental horticulture,61, 129-138 (2017) https://www.elibrary.ru/item.asp?id=29818034 (In Russ.)

15. M. Kalinowska, A. Bielawskab, H. Lewandowska-Siwkiewiczc, W. Priebed, W. Lewandowski. Plant Physiology and Biochemistry, 84, 169-188 (2014) https://doi.org/10.1016/j.plaphy.2014.09.006

16. O.G. Belous, E.G. Bazba. Pomiculture and small fruits culture in Russia, 53, 47-55 (2018) https://www.elibrary.ru/item.asp?id=35325864 (In Russ.)

17. S. Gholi-Tolouie, M. Davari, N. Sokhandan-Bashir, M. Sedghi. Iranian Journal of Plant Physiology, 8(2), 2345-2351 2018 https://doi.org/10.22034/ijpp.2018.539110

18. S.M. Motyleva, A.A. Borisova. Horticulture and viticulture, 6, 12-18 (2018) https://doi.org/10.31676/0235-2591-2018-6-12-18. (In Russ.)

19. E.N. Sedov, M.A. Makarkina, Z.M. Serova. Vavilov Journal of Genetics and Breeding, 18(3), 540-547 (2014) https://vavilov.elpub.ru/jour/article/view/280/0

20. Y. Zhanga, T. Lubberstedtb, M. Xua. Journal of Genetics and Genomics, 40(1), 23 35 (2012) https://doi.org/10.1016/j.jgg.2012.11.003

21. N.V. Pshenichny, O.G. Belous. Subtropical and ornamental horticlture. 1(46), 45-51 (2012) https://www.elibrary.ru/item.asp?id=18184427 
22. Y. Osroosh, T. Peters, C.S. Campbell. Journal of Irrigation and Drainage Engineering, 141(9), 1943-4774 (2015) $\quad$ http://doi/10.1061/\%28ASCE\%29IR.1943$\underline{4774.0000877}$

23. X. Li, X. Chen, X. Cui. Agricultural Sciences, 3(4), 562-566 (2012).

https://doi.org/10.4236/as.2012.34067

24. P. Kachroo, A. Kachroo. In book: Molecular Plant Immunity. 2, $55-79$ (2012) https://doi.org/10.1002/9781118481431.ch4

25. N.N. Karpun, E.B. Yanushevskaya, E.V. Mikhailova. Agricultural biology, 50(5), 540-549 (2015) https://doi.org/10.15389/agrobiology.2015.5.540rus

26. I.V. Maksimov, A.V. Sorokan. Plant physiology, 58(2), 243-251, (2011) http://www.rusplant.ru/index.php?page=Posts.ViewPost\&id=418

27. Gholi-Tolouie, S., M. Davari, N. Sokhandan-Bashir, and M. Sedghi. Iranian Journal of Plant Physiology, 8(2), 2345-23512018 https://doi.org/10.22034/ijpp.2018.539110 